\title{
Effect of fungicides applied at the flowering stage of winter oilseed rape on the yield quantity and quality of seeds
}

\author{
Wpływ stosowania fungicydów w okresie kwitnienia na wysokość \\ i jakość plonu nasion rzepaku ozimego
}

\author{
Agnieszka Mączyńska*, Barbara Krzyzińska, Joanna Banachowska
}

\begin{abstract}
Summary
Strict plot trial was carried out on the experimental field of Institute of Plant Protection - National Research Institute, Sośnicowice Branch during the growing seasons of 2011/2012-2012/2013. Three different varieties of winter oilseed rape were sown at their optimal sowing time after a cereal forecrop. To protect the crop against Sclerotina sclerotiorum and pod diseases three fungicides, approved for use in Poland, based on active substances that belong to different chemical groups were applied at three different timings: at the beginning of flowering (BBCH 60-61), full flowering (BBCH 64-65) and end of flowering (BBCH 67-69). The results indicate that both weather conditions and the timing of fungicide treatment significantly affect oilseed rape yield quality and quantity. Under the conditions of early infection, the application of fungicides at the beginning of the flowering stage decreases the level of infection in harvested seeds, caused mostly by Alternaria genera of fungi, which significantly worsen the quality of sowing material. Fungicides applied in the crop under stress or in poor condition had a negative impact on the content of oilseed in rape seeds. This reaction was observed to be the stronger: the weaker was the condition of oilseed rape plants.
\end{abstract}

Key words: winter oilseed rape; fungicide; disease; yield; quality; sowing material

\section{Streszczenie}

W sezonach wegetacyjnych 2011/2012-2012/2013 na polu doświadczalnym Instytutu Ochrony Roślin - Państwowego Instytutu Badawczego, Oddział Sośnicowice przeprowadzono ścisłe doświadczenie poletkowe. Trzy odmiany rzepaku ozimego wysiewano w optymalnym terminie, po przedplonie zbożowym. W celu ochrony rzepaku przed zgnilizną twardzikową i chorobami łuszczyn wybrano 3 dopuszczone do obrotu w Polsce fungicydy oparte na substancjach czynnych z różnych grup chemicznych, które aplikowano w trzech terminach: w początkowej fazie kwitnienia (BBCH 60-61), w pełni kwitnienia (BBCH 64-65) oraz w końcowej fazie kwitnienia rzepaku (BBCH 67-69). Na podstawie uzyskanych wyników można stwierdzić, iż warunki pogodowe oraz termin zastosowania fungicydów mają istotny wpływ na parametry ilościowe i jakość zebranego plonu rzepaku. W warunkach wczesnych infekcji, zastosowanie fungicydów na początku fazy kwitnienia rzepaku przekłada się na zmniejszenie zasiedlenia zebranych nasion rzepaku przez grzyby, głównie rodzaju Alternaria, które w sposób znaczący pogarszają jakość materiału siewnego. Zastosowanie fungicydów w warunkach stresu dla roślin rzepaku i słabej ich kondycji wpływa ujemnie na zawartość oleju w nasionach. Reakcja ta jest tym silniejsza im słabsza jest kondycja roślin.

Słowa kluczowe: rzepak ozimy; choroby; fungicydy; plon; jakość; materiał siewny

Instytut Ochrony Roślin - Państwowy Instytut Badawczy

Oddział Sośnicowice

Gliwicka 29, 44-153 Sośnicowice

*corresponding author: a.maczynska@ior.gliwice.pl 


\section{Wstęp / Introduction}

Uprawa rzepaku wymaga dużych nakładów finansowych, gdyż zakres warunków agrotechnicznych jakie muszą być spełnione, aby poniesione koszty zostały zrekompensowane jest bardzo szeroki (Baradough 1989; Grant i Bailey 1993). Stosowane metody uprawy winny gwarantować nie tylko uzyskanie wysokiego plonu nasion, ale także dobrej jego jakości (Wielebski 2009). Pełne wykorzystanie potencjału plonowania roślin uprawnych jest możliwe pod warunkiem stworzenia optymalnych warunków wzrostu, w tym ochrony przed patogenami (Nowak i wsp. 2005).

Przy wzrastającej intensyfikacji uprawy rzepaku, każdego roku w warunkach Polski południowo-środkowej odnotowuje się zagrożenie ze strony zgnilizny twardzikowej [Sclerotinia sclerotiorum (Lib.) de Bary] oraz chorób łuszczyn - czerni krzyżowych (Alternaria sp.) i szarej pleśni (Botrytis cinerea Pers.). Zdrowotność roślin zależy od wielu czynników zarówno agrotechnicznych, jak i pogodowych, a także zastosowanych $\mathrm{w}$ odpowiednim terminie fungicydów. Wymiernym rezultatem współdziałania tych czynników staje się wysoki i dobrej jakości plon nasion (Jajor i wsp. 2013).

Celem przeprowadzonych badań było określenie wpływu różnych terminów stosowania fungicydów w okresie kwitnienia rzepaku ozimego na wysokość i jakość plonu oraz wartość siewną zebranych nasion.

\section{Materiały i metody / Materials and methods}

W sezonach wegetacyjnych 2011/2012-2012/2013 na polu doświadczalnym Instytutu Ochrony Roślin - Państwowego Instytutu Badawczego, Oddział Sośnicowice przeprowadzono ścisłe doświadczenie poletkowe. Rzepak ozimy 3 odmian, uprawianych $\mathrm{w}$ rejonie Polski południowo-środkowej: Visby F1, Titan F1 i Digger wysiewano w optymalnym terminie, po przedplonie zbożowym. W celu ochrony rzepaku przed zgnilizną twardzikową i chorobami łuszczyn wybrano 3 dopuszczone do obrotu w Polsce fungicydy oparte na substancjach czynnych (s.cz.) z róż- nych grup chemicznych, które aplikowano $\mathrm{w}$ trzech terminach: w początkowej fazie kwitnienia (BBCH 60-61), w pełni kwitnienia (BBCH 64-65) oraz w końcowej fazie kwitnienia rzepaku (BBCH 67-69). Wykaz s.cz. fungicydów oraz terminy ich stosowania zmieszczono w tabeli 1 .

W fazie dojrzewania łuszczyn oceniano procent roślin porażonych przez $S$. sclerotiorum. W tym samym czasie przeprowadzono analizę porażenia łuszczyn, a wyniki przedstawiono jako \% porażonych łuszczyn.

W badaniach oceniano plon i masę tysiąca nasion oraz analizowano wpływ ochrony fungicydowej na zawartość oleju w zebranych nasionach rzepaku ozimego. Ponadto, po zbiorze, w terminie siewu rzepaku, w warunkach laboratoryjnych zbadano energię i zdolność kiełkowania nasion rzepaku. Zebrane nasiona, odkażano powierzchniowo w $2 \%$ podchlorynie sodu przez 3 minuty, a następnie płukano pod bieżącą wodą i wykładano na zakwaszoną pożywkę glukozowo-ziemniaczaną (PDA - Potato Dextrose Agar). Po okresie inkubacji oceniano makro- i mikroskopowe cechy kultur i na tej podstawie przypisywano je do odpowiednich rodzajów lub gatunków.

Analizie statystycznej zostały poddane średnie $\mathrm{z}$ trzech odmian (Visby F1, Titan F1 i Digger) oraz średnie ze stosowania trzech s.cz. (prochloraz, azoksystrobina, dimoksystrobina + boskalid). Obliczenia wykonano przy pomocy programu STATISTICA v. 8.0, stosując analizę wariancji ANOVA. Wyniki porównano za pomocą testu statystycznego Duncana przy poziomie istotności $\mathrm{p}=0,05$.

\section{Wyniki i dyskusja / Results and discussion}

Warunki termiczne i wilgotnościowe w okresie wegetacji w obydwóch latach badań, odbiegały od średnich z wielolecia (tab. 2). Jesień 2011 i 2012 roku była ciepła. Średnie temperatury powietrza w tym czasie były wyższe od średniej wieloletniej. Rzepak ozimy w okresie jesiennego rozwoju ma małe wymagania wodne. Zdaniem Muśnickiego (1989) przeciętne opady na poziomie 60-80 mm w okresie od wschodów do zahamowania wegetacji jesiennej, w pełni pokrywają potrzeby wodne

Tabela 1. Wykaz substancji czynnych fungicydów oraz terminy ich stosowania w ochronie rzepaku ozimego

Table 1. List of active substances of fungicides and terms of their application in winter oilseed rape

\begin{tabular}{|c|c|c|c|}
\hline $\begin{array}{l}\text { Substancja czynna } \\
\text { Active substance }\end{array}$ & $\begin{array}{c}\text { Zawartość substancji czynnej } \\
\text { Content of active substance } \\
{[\mathrm{g} / \mathrm{l}]}\end{array}$ & $\begin{array}{l}\text { Termin aplikacji } \\
\text { Term of application }\end{array}$ & $\begin{array}{c}\text { Dawka fungicydu } \\
\text { Fungicide dose } \\
{[1 / \mathrm{ha}]}\end{array}$ \\
\hline \multirow{3}{*}{ Prochloraz } & \multirow{3}{*}{450} & ВBCH 60-61 & 1,5 \\
\hline & & ВBCH 64-65 & 1,5 \\
\hline & & ВBCH 67-69 & 1,5 \\
\hline \multirow{3}{*}{ Azoxystrobin } & \multirow{3}{*}{250} & ВBCH 60-61 & 1,0 \\
\hline & & BBCH 64-65 & 1,0 \\
\hline & & ВBCH 67-69 & 1,0 \\
\hline \multirow{3}{*}{$\begin{array}{l}\text { Dimoxystrobin }+ \\
\text { boscalid }\end{array}$} & \multirow{3}{*}{$200+200$} & BBCH 60-61 & 0,5 \\
\hline & & ВBCH 64-65 & 0,5 \\
\hline & & ВBCH 67-69 & 0,5 \\
\hline
\end{tabular}


gatunku. W obydwóch sezonach nie stwierdzono niedoborów wody $\mathrm{w}$ okresie jesiennym. Rzepak ozimy przed wejściem w stan zimowego spoczynku był wyrośnięty i dobrze rozkrzewiony. Przedłużenie jesiennej wegetacji do grudnia w 2011 roku, a następnie gwałtowne i długotrwałe ochłodzenie w styczniu 2012 roku oraz brak okrywy śnieżnej, doprowadziło do przemarznięcia systemu korzeniowego rzepaku i w konsekwencji złego przezimowania roślin. Odpowiednio zahartowane rośliny rzepaku jesienią 2012 roku, po długiej zimie, z zalegającą pokrywą śnieżną, wiosną 2013 roku były w bardzo dobrej kondycji.

Diametralnie różne były również warunki pogodowe panujące w okresie wiosennej wegetacji. Występujący w maju 2012 roku, czyli w fazie kwitnienia, niedobór opadów deszczu oraz duża amplituda temperatur spowodowały znaczny stres dla roślin rzepaku, który został spotęgowany występującymi w połowie maja przymrozkami (tab. 2). Skutkiem niesprzyjających warunków pogodo- wych była zła kondycja i wigor rzepaku w czasie kwitnienia. To właśnie w czasie kwitnienia rzepak najbardziej narażony jest na brak wody (Budzyński i Ojczyk 1996), stres termiczny (Angadi i wsp. 2000; Kutcher i wsp. 2010) i wiosenne przymrozki (Koźmiński i wsp. 1993). Zupełnie inaczej przedstawiała się sytuacja wiosną 2013 roku. Na początku okresu wegetacyjnego, mimo opadów deszczu dwukrotnie niższych od średniej wieloletniej, uwilgotnienie wierzchniej warstwy gleby zabezpieczało potrzeby wodne roślin. W maju i czerwcu odnotowano obfite, ulewne deszcze, również o charakterze burzowym. Suma opadów w tych miesiącach wyniosła $306,1 \mathrm{~mm}$, co stanowi połowę całorocznych opadów.

Warunki pogodowe w końcowej fazie dojrzewania rzepaku były również odmienne w dwóch latach badań (tab. 2). W 2012 roku suma opadów znacznie przewyższała średnią $\mathrm{z}$ wielolecia. Intensywne opady deszczu

Tabela 2. Charakterystyka warunków pogodowych w sezonach 2011/2012 i 2012/2013

Table 2. Description of weather conditions in 2011/2012 and 2012/2013

\begin{tabular}{|c|c|c|c|c|c|c|}
\hline \multirow{2}{*}{ Miesiąc-Month } & \multicolumn{3}{|c|}{$\begin{array}{l}\text { Średnia temperatura - Average temperature } \\
{\left[{ }^{\circ} \mathrm{C}\right]}\end{array}$} & \multicolumn{3}{|c|}{$\begin{array}{l}\text { Suma opadów }- \text { Sum of rainfall } \\
{[\mathrm{mm}]}\end{array}$} \\
\hline & $2011 / 2012$ & $2012 / 2013$ & $\begin{array}{l}\text { wieloletnia } \\
\text { many years }\end{array}$ & $2011 / 2012$ & $2012 / 2013$ & $\begin{array}{l}\text { wieloletnia } \\
\text { many years }\end{array}$ \\
\hline Wrzesień - September & 15,6 & 14,3 & 13,0 & 23,9 & 45,7 & 60,7 \\
\hline Październik - October & 9,2 & 8,8 & 8,4 & 32,9 & 98,0 & 42,2 \\
\hline Listopad - November & 3,1 & 6,0 & 3,2 & 0,1 & 9,6 & 44,9 \\
\hline Grudzień - December & 2,1 & $-1,6$ & $-0,8$ & 36,5 & 27,6 & 45,9 \\
\hline Styczeń - January & $-0,6$ & $-2,1$ & $-1,2$ & 62,1 & 46,6 & 39,3 \\
\hline Luty - February & $-5,6$ & 0,2 & $-0,2$ & 37,1 & 23,2 & 35,3 \\
\hline Marzec-March & 4,6 & $-0,2$ & 3,3 & 29,7 & 41,4 & 46,4 \\
\hline Kwiecień - April & 9,8 & 9,0 & 8,6 & 52,8 & 22,4 & 45,7 \\
\hline Maj-May & 15,1 & 14,1 & 13,8 & 26,9 & 170,3 & 71,6 \\
\hline Czerwiec-June & 17,4 & 17,1 & 16,6 & 80,0 & 135,8 & 83,3 \\
\hline Lipiec - July & 20,2 & 19,7 & 18,9 & 119,0 & 46,5 & 92,6 \\
\hline
\end{tabular}

Tabela 3. Wpływ terminu aplikacji fungicydów w okresie kwitnienia na ograniczenie występowanie chorób rzepaku ozimego

Table 3. Effect of fungicide treatment applied at flowering on the control of diseases in winter oilseed rape

\begin{tabular}{|c|c|c|c|c|c|c|c|c|c|}
\hline \multirow{3}{*}{$\begin{array}{c}\text { Termin aplikacji } \\
\text { Term } \\
\text { of application }\end{array}$} & \multirow{2}{*}{\multicolumn{3}{|c|}{$\begin{array}{l}\text { \% porażonych roślin przez } \\
\% \text { of infected plants by } \\
\text { Sclerotinia sclerotiorum }\end{array}$}} & \multicolumn{6}{|c|}{$\begin{array}{c}\% \text { porażonej powierzchni łuszczyn przez } \\
\% \text { of infected pod area by }\end{array}$} \\
\hline & & & & \multicolumn{3}{|c|}{ Alternaria spp. } & \multicolumn{3}{|c|}{ Botrytis cinerea } \\
\hline & 2012 & 2013 & $\begin{array}{l}\text { średnio } \\
\text { average }\end{array}$ & 2012 & 2013 & $\begin{array}{l}\text { średnio } \\
\text { average }\end{array}$ & 2012 & 2013 & $\begin{array}{l}\text { średnio } \\
\text { average }\end{array}$ \\
\hline $\begin{array}{l}\text { Kontrola } \\
\text { Untreated }\end{array}$ & $29,00 \mathrm{~d}$ & $35,67 \mathrm{e}$ & $32,33 \mathrm{c}$ & $4,08 \mathrm{~b}$ & $31,92 \mathrm{~d}$ & $18,00 \mathrm{c}$ & $23,83 \mathrm{c}$ & $35,58 \mathrm{~d}$ & $29,71 \mathrm{c}$ \\
\hline BBCH 60-61 & $11,67 \mathrm{~b}$ & $17,00 \mathrm{c}$ & $14,33 \mathrm{~b}$ & $1,11 \mathrm{a}$ & $3,92 \mathrm{~b}$ & $2,51 \mathrm{a}$ & $9,97 \mathrm{a}$ & $19,03 \mathrm{~b}$ & $14,50 \mathrm{~b}$ \\
\hline ВBCH 64-65 & $10,89 \mathrm{~b}$ & $6,22 \mathrm{a}$ & $8,56 \mathrm{a}$ & $0,78 \mathrm{a}$ & $5,67 \mathrm{~b}$ & $3,22 \mathrm{ab}$ & $10,22 \mathrm{a}$ & $17,61 \mathrm{~b}$ & $13,92 \mathrm{~b}$ \\
\hline BBCH 67-69 & $12,00 \mathrm{~b}$ & $17,00 \mathrm{c}$ & $14,50 \mathrm{~b}$ & $0,64 \mathrm{a}$ & $7,86 \mathrm{c}$ & $4,25 \mathrm{~b}$ & $11,17 \mathrm{a}$ & $9,19 \mathrm{a}$ & $10,18 \mathrm{a}$ \\
\hline $\begin{array}{l}\text { Średnio } \\
\text { Average }\end{array}$ & $13,4 \mathrm{a}$ & $15,2 \mathrm{~b}$ & & $1,65 \mathrm{a}$ & $12,34 \mathrm{~b}$ & & $13,80 \mathrm{a}$ & $20,35 \mathrm{~b}$ & \\
\hline
\end{tabular}

Jednakowymi literami oznaczono wartości nie różniące się istotnie - Values with no significant differences were marked with the same letter 
Tabela 4. Plonowanie i parametry plonu rzepaku ozimego w zależności od terminu aplikacji fungicydów w czasie kwitnienia

Table 4. Yield and yield parameters of winter oilseed rape depending on the term of fungicide treatment at flowering

\begin{tabular}{|c|c|c|c|c|c|c|c|c|c|}
\hline \multirow{2}{*}{$\begin{array}{l}\text { Termin aplikacji } \\
\text { Term of application }\end{array}$} & \multicolumn{3}{|c|}{$\begin{array}{l}\text { Plon } \\
\text { Yield } \\
{[\mathrm{t} / \mathrm{ha}]}\end{array}$} & \multicolumn{3}{|c|}{$\begin{array}{c}\text { Masa tysiąca ziaren } \\
\text { Thousand grain weight } \\
{[\mathrm{g}]}\end{array}$} & \multicolumn{3}{|c|}{$\begin{array}{l}\text { Zawartość oleju [\% SM] } \\
\text { Oil content }[\% \text { DW] }\end{array}$} \\
\hline & 2012 & 2013 & $\begin{array}{l}\text { średnio } \\
\text { average }\end{array}$ & 2012 & 2013 & $\begin{array}{l}\text { średnio } \\
\text { average }\end{array}$ & 2012 & 2013 & $\begin{array}{l}\text { średnio } \\
\text { average }\end{array}$ \\
\hline $\begin{array}{l}\text { Kontrola } \\
\text { Untreated }\end{array}$ & $3,06 \mathrm{a}$ & $3,40 \mathrm{c}$ & $3,23 \mathrm{~b}$ & $6,28 \mathrm{~b}$ & $5,55 \mathrm{a}$ & $5,92 \mathrm{~b}$ & $46,73 \mathrm{c}$ & $46,39 \mathrm{c}$ & $46,56 \mathrm{~b}$ \\
\hline BBCH 60-61 & $3,36 \mathrm{c}$ & $4,25 \mathrm{e}$ & $3,81 \mathrm{a}$ & $6,50 \mathrm{c}$ & $5,55 \mathrm{a}$ & $6,02 \mathrm{a}$ & $45,64 \mathrm{~b}$ & $46,49 \mathrm{c}$ & $46,07 \mathrm{a}$ \\
\hline BBCH 64-65 & $3,19 \mathrm{ab}$ & $3,77 \mathrm{~d}$ & $3,48 \mathrm{c}$ & $6,44 \mathrm{c}$ & $5,61 \mathrm{a}$ & $6,02 \mathrm{a}$ & $45,04 \mathrm{a}$ & $46,65 \mathrm{c}$ & $45,85 \mathrm{a}$ \\
\hline ВBCH 67-69 & $3,26 \mathrm{cb}$ & $4,17 \mathrm{e}$ & $3,72 \mathrm{a}$ & $6,44 \mathrm{c}$ & $5,55 \mathrm{a}$ & $6,00 \mathrm{a}$ & $45,54 \mathrm{~b}$ & $46,50 \mathrm{c}$ & $46,02 \mathrm{a}$ \\
\hline $\begin{array}{l}\text { Średnio } \\
\text { Average }\end{array}$ & $3,22 \mathrm{a}$ & $3,90 \mathrm{~b}$ & & $6,42 \mathrm{~b}$ & $5,56 \mathrm{a}$ & & $45,74 \mathrm{a}$ & $46,51 \mathrm{~b}$ & \\
\hline
\end{tabular}

Jednakowymi literami oznaczono wartości nie różniące się istotnie - Values with no significant differences were marked with the same letter

Tabela 5. Energia i zdolność kiełkowania oraz zasiedlenie zebranych nasion przez grzyby rodzaju Alternaria w zależności od terminu aplikacji fungicydów w czasie kwitnienia

Table 5. Germination energy and viability as well as infection by Alternaria genera fungi of harvested seeds depending on the term of fungicide treatment at flowering

\begin{tabular}{|c|c|c|c|c|c|c|c|c|c|}
\hline \multirow[t]{2}{*}{$\begin{array}{l}\text { Termin aplikacji } \\
\text { Term of application }\end{array}$} & \multicolumn{3}{|c|}{$\begin{array}{c}\text { Energia kiełkowania } \\
\text { Germination energy of harvested seeds } \\
{[\%]}\end{array}$} & \multicolumn{3}{|c|}{$\begin{array}{c}\text { Zdolność kiełkowania } \\
\text { Germination viability } \\
\text { of harvested seeds } \\
{[\%]}\end{array}$} & \multicolumn{3}{|c|}{$\begin{array}{c}\text { Nasiona zasiedlone } \\
\text { przez Alternaria spp. } \\
\text { Seeds infected by Alternaria spp. } \\
{[\%]}\end{array}$} \\
\hline & 2012 & 2013 & $\begin{array}{l}\text { średnio } \\
\text { average }\end{array}$ & 2012 & 2013 & $\begin{array}{l}\text { średnio } \\
\text { average }\end{array}$ & 2012 & 2013 & $\begin{array}{l}\text { średnio } \\
\text { average }\end{array}$ \\
\hline $\begin{array}{l}\text { Kontrola } \\
\text { Untreated }\end{array}$ & $71,00 \mathrm{~d}$ & $47,17 \mathrm{~b}$ & $59,08 \mathrm{~b}$ & $90,83 \mathrm{c}$ & $80,67 \mathrm{~b}$ & $85,75 \mathrm{~b}$ & $12,25 \mathrm{c}$ & $46,67 \mathrm{e}$ & $29,46 \mathrm{c}$ \\
\hline ВBCH 60-61 & $56,44 \mathrm{c}$ & $51,11 \mathrm{bc}$ & $53,78 \mathrm{~b}$ & $82,33 \mathrm{~b}$ & $90,50 \mathrm{c}$ & $86,42 \mathrm{~b}$ & $3,92 \mathrm{a}$ & $8,67 \mathrm{~b}$ & $6,29 \mathrm{a}$ \\
\hline BBCH 64-65 & $35,06 \mathrm{a}$ & $53,50 \mathrm{bc}$ & $44,28 \mathrm{a}$ & $73,11 \mathrm{a}$ & $86,33 \mathrm{bc}$ & 79,72 a & $3,50 \mathrm{a}$ & $13,25 \mathrm{c}$ & $8,38 \mathrm{~b}$ \\
\hline ВBCH 67-69 & $45,06 \mathrm{~b}$ & $49,89 \mathrm{bc}$ & $47,47 \mathrm{a}$ & $81,11 \mathrm{~b}$ & $89,00 \mathrm{c}$ & $85,06 \mathrm{~b}$ & $1,58 \mathrm{a}$ & $17,42 \mathrm{~d}$ & $9,50 \mathrm{~b}$ \\
\hline $\begin{array}{l}\text { Średnio } \\
\text { Average }\end{array}$ & $50,42 \mathrm{a}$ & 51,89 a & & $81,85 \mathrm{a}$ & $86,63 \mathrm{~b}$ & & $5,31 \mathrm{a}$ & $21,50 \mathrm{~b}$ & \\
\hline
\end{tabular}

Jednakowymi literami oznaczono wartości nie różniące się istotnie - Values with no significant differences were marked with the same letter

w połączeniu ze słabą kondycją roślin, doprowadziły do wylegania rzepaku. W 2013 roku w czasie dojrzewania łuszczyn suma opadów była o połowę niższa niż średnia wieloletnia. Ze względu na duże nagromadzenie wilgoci $\mathrm{w}$ glebie po majowych i czerwcowych opadach, nie wpłynęło to jednak negatywnie na kondycję rzepaku.

Jednym z ważniejszych czynników mających wpływ na zdrowotność roślin jest przebieg pogody w sezonie wegetacyjnym (Dunker i Tiedemann 2004; Gwiazdowski i wsp. 2004; Jajor i wsp. 2008), co również obserwowano w badaniach własnych (tab. 2, 3). W 2012 roku ze względu na panującą suszę, rozwój infekcji nastąpił dopiero pod koniec drugiej dekady czerwca. Parna i burzowa pogoda w ostatnich dniach tego miesiąca spowodowała gwałtowny wzrost zagrożenia chorobami. Szara pleśń na łuszczynach, w obiekcie kontrolnym objęła swym zasięgiem blisko $24 \%$ ich powierzchni, a zgnilizna twardzikowa $29 \%$ roślin. Ze względu na to, że grzyby rodzaju Alternaria do kiełkowania zarodników i procesu zakażania potrzebują wody lub według innych źródeł wysokiej wilgotności (Humpherson-Jones 1992; Shrestha i wsp. 2005; Rimmer i wsp. 2007), w 2012 roku, przy długotrwałych niedoborach wody, poziom porażenia łuszczyn wyniósł zaledwie
4\% (tab. 3). W roku 2013, przy silnych opadach deszczu i wysokiej wilgotności powietrza, zarówno czerń krzyżowych, jak i szara pleśń rozwijały się już na liściach rzepaku. Poziom porażenia łuszczyn był wyższy niż w 2012 roku i wyniósł w obiekcie kontrolnym blisko 31\% ich powierzchni przez grzyby rodzaju Alternaria oraz ponad 35\% ich powierzchni przez grzyb Botrytis cinerea. W 2013 roku stwierdzono również o ponad 6\% więcej roślin $\mathrm{z}$ objawami zgnilizny twardzikowej w porównaniu do poprzedniego sezonu wegetacyjnego.

Właściwa ochrona rzepaku $\mathrm{w}$ okresie kwitnienia ma kluczowe znacznie dla osiągnięcia sukcesu w jego uprawie. W przeprowadzonych badaniach termin aplikacji różnicował efektywność zastosowanych fungicydów jedynie w 2013 roku, w którym porażenie było wyższe niż w 2012 roku (tab. 3). Średnio dla dwóch lat badań najlepszą skuteczność w ochronie rzepaku przed sprawcą zgnilizny twardzikowej odnotowano po aplikacji przeprowadzonej w pełni kwitnienia. Brachaczek i wsp. (2012) również stwierdzili, iż termin stosowania fungicydów ma istotny wpływ na stopień ograniczenia porażenia przez S. sclerotiorum. W warunkach silnego porażenia liści i łuszczyn przez grzyby rodzaju Alternaria zaobserwo- 
wano wyraźny wpływ terminów stosowania fungicydów na zdrowotność łuszczyn rzepaku ozimego. Im wcześniej zastosowano ochronę chemiczną, tym porażenie łuszczyn było słabsze (Mączyńska i wsp. 2001). W niniejszej pracy istotnie lepszą ochronę łuszczyn przed czernią krzyżowych uzyskano w wyniku aplikacji fungicydów w początkowej fazie kwitnienia, niż po zabiegu wykonanym w końcowej fazie. Ze względu na późną infekcję przez $B$. cinerea, łuszczyny rzepaku przed szarą pleśnią najskuteczniej zabezpieczał zabieg przeprowadzony w końcowej fazie kwitnienia rzepaku.

$\mathrm{Na}$ plonowanie rzepaku ma wpływ wiele czynników, a rozwój chorób i ich poziom zwalczania to tylko dwa z nich (Bankina i wsp. 2010). Rzepak należy do gatunków silnie reagujących na zmieniające się warunki klimatyczne, o czym świadczy uzyskanie różnic w plonowaniu, w poszczególnych latach (Kotecki i wsp. 2004; Kulig i wsp. 2010, 2012). W przeprowadzonych badaniach warunki pogodowe oraz kondycja roślin rzepaku w momencie aplikacji miała istotne znaczenie dla uzyskanego plonu (tab. 4). Wpływ stosowania fungicydów w okresie wegetacji rzepaku ozimego na wartość masy tysiąca nasion kształtował się różnie w latach badań (tab. 4). W 2012 roku ochrona rzepaku przy użyciu fungicydów, bez względu na termin ich aplikacji w czasie kwitnienia, wpłynęła na istotny wzrost tego parametru, natomiast w 2013 roku nie stwierdzono wpływu zastosowanych fungicydów na mase tysiąca nasion. Barszczak i Barszczak (1995) w swoich badaniach stwierdzili, że niedobór wody w czasie kwitnienia rzepaku zwiększa masę tysiąca nasion, co też odnotowano w badaniach własnych. Masa tysiąca nasion w 2012 roku była istotnie wyższa niż w 2013 roku.

Podstawowym kryterium oceny jakościowej nasion rzepaku w technologii olejarskiej jest zawartość tłuszczu, która może być kształtowana nie tylko przez czynniki genetyczne, ale także przez czynniki siedliskowe i agrotechniczne (Asare i Scarisbrick 1995; Mendham 1995; Muśnicki i wsp. 1999; Kotecki i wsp. 2001). Większa zawartość oleju w nasionach występuje w chłodnych latach o większej ilości opadów, mniejsze natomiast w latach ciepłych (Bartkowiak-Broda i wsp. 2005), co zostało również potwierdzone w niniejszych badaniach. Zawartość oleju w nasionach rzepaku w 2012 roku była istotnie niższa niż w 2013 roku (tab. 4). Fungicydy zastosowane w warunkach stresu dla roślin rzepaku i słabej ich kondycji w roku 2012, wpłynęły ujemnie na zawartość oleju w nasionach. Reakcja była tym silniejsza, im słabsza była kondycja roślin. Istotne zmiany w zawartości tłuszczu po zastosowaniu środków ochrony roślin odnotowali również Murawa i Warmiński (2005). W 2013 roku, kiedy rzepak był $\mathrm{w}$ bardzo dobrej kondycji nie stwierdzono wpływu stosowania fungicydów w okresie kwitnienia na zawartość oleju w jego w nasionach.

Dobrej jakości materiał siewny stanowi podstawę uzyskania szybkich i wyrównanych wschodów rzepaku ozimego. Materiał siewny o obniżonej zdolności i energii kiełkowania nie daje gwarancji, że $\mathrm{z}$ takich nasion wyrosną silne rośliny (Wałkowski 2012). W przeprowadzonych badaniach zastosowanie fungicydów na rzepak będący w słabej kondycji (2012 rok) wpłynęło negatywnie na energię i zdolność kiełkowania nasion (tab. 5). Zupełnie odmienną reakcję stwierdzono stosując zabiegi ochronne na rzepak będący w dobrej kondycji (2013 rok). Aplikacja fungicydów we wszystkich terminach, wpłynęła na istotne polepszenie zdolności kiełkowania. Pozytywny wpływ fungicydów na zdolności kiełkowania nasion łubinu żółtego odnotowali w swojej pracy Szukała i wsp. (2006). Użycie do siewu materiału siewnego porażonego przez patogeny może stanowić niebezpieczeństwo zarówno dla siewek, jak i roślin. W niniejszej pracy z zebranych nasion rzepaku, najczęściej izolowano grzyby rodzaju Alternaria, co jest zgodne $\mathrm{z}$ danymi literaturowymi (Brazauskiene i Petraitiene 2006; Jajor i wsp. 2013). Laboratoryjna ocena wykazała, że zastosowanie fungicydów w okresie kwitnienia ograniczyło istotnie porażenie łuszczyn i nasion przez grzyby rodzaju Alternaria. W warunkach słabej presji infekcyjnej (2012 rok) procent porażonych nasion nie zależał od terminu aplikacji fungicydów. W 2013 roku, kiedy porażenie łuszczyn było silne, istotne znaczenie dla zasiedlenia nasion przez grzyby rodzaju Alternaria miał termin zastosowania ochrony fungicydowej. Początek kwitnienia rzepaku w 2013 roku był najlepszym terminem aplikacji fungicydów zarówno dla ochrony łuszczyn przed czernią krzyżowych, jak i dla ograniczenia zasiedlenia zebranych nasion przez grzyby rodzaju Alternaria.

\section{Wnioski / Conclusions}

1. Dobre działanie fungicydów zastosowanych w okresie kwitnienia przekłada się na wzrost plonowania i poprawę wartości siewnej nasion rzepaku jedynie wtedy, gdy rośliny zachowują dobrą kondycję i wigor w czasie aplikacji, a równocześnie poddane są silnemu wpływowi grzybów patogenicznych.

2. Konsekwencją dobrania optymalnego terminu ochrony rzepaku ozimego przy użyciu fungicydów w czasie kwitnienia jest ograniczenie zasiedlenia zebranych nasion rzepaku przez grzyby chorobotwórcze, głównie rodzaju Alternaria, które w sposób znaczący pogarszają jakość materiału siewnego.

3. W warunkach wczesnych infekcji oraz prawidłowego wzrostu i rozwoju roślin rzepaku, zastosowanie fungicydów na początku fazy kwitnienia przekłada się na uzyskanie wyższego plonowania niż po aplikacji przeprowadzonej $\mathrm{w}$ fazie pełni kwitnienia, a zdrowotność zebranych nasion jest lepsza $w$ porównaniu ze zdrowotnością nasion pochodzących z plonu po późniejszych terminach aplikacji.

4. Zastosowanie fungicydów w warunkach stresowych dla roślin rzepaku i wykazujących słabą kondycję oraz wigor wpływa ujemnie na energię i zdolność kiełkowania oraz zawartość oleju w zebranych nasionach. Reakcja ta jest tym silniejsza im słabsza jest kondycja roślin.

5. Warunki pogodowe oraz termin zastosowania fungicydów mają istotny wpływ na parametry ilościowe i jakość zebranego plonu nasion rzepaku ozimego. 


\section{Literatura / References}

Angadi S.V., Cutforth H.W., Miller P.R., McConkey B.G., Entz M.H., Brandt S.A., Volkmar K.M. 2000. Response of three Brassica species to high temperature stress during reproductive growth. Canadian Journal of Plant Science 80 (4): 693-701.

Asare E., Scarisbrick D.H. 1995. Rate of nitrogen and sulfur fertilizers on yield, yield components and seed quality of oilseed rape (Brassica napus L.). Field Crops Research 44 (1): 41-46.

Bankina B., Balodius O., Gaile Z. 2010. Advances of fungicide application for winter oilseed rape. p. 157-176. In: „Fungicide” (O. Carisse, ed.). InTech, Rijeka, 538 pp.

Baradough P.B. 1989. Root growth, macronutrient uptake dynamics soil fertility requirements of a high - yielding winter oilseed rape crop. Plant Soil 119: 59-70.

Barszczak T., Barszczak Z. 1995. Wpływ nawożenia azotowego, wilgotności i zakwaszenia gleby na plony oraz zawartość tłuszczu i białka w nasionach odmian rzepaku ozimego. Rośliny Oleiste - Oilseed Crops XVI (1): 165-172.

Bartkowiak-Broda I., Wałkowski T., Ogrodowczyk M. 2005. Przyrodnicze i agrotechniczne możliwości kształtowania jakości nasion rzepaku. Pamiętnik Puławski 139: 7-25.

Brachaczek A., Kaczmarek J., Jędryczka M. 2012. Optymalizacja terminu zabiegów fungicydowych przeciw zgniliźnie twardzikowej na rzepaku. [Optimization of fungicide treatment dates against sclerotinia stem rot on oilseed rape]. Progress in Plant Protection/Postępy w Ochronie Roślin 52 (4): 983-987.

Brazauskiene I., Petraitiene E. 2006. The occurrence of alternaria blight (Alternaria spp.) and phoma stem canker (Phoma lingam) on oilseed rape in central Lithuania and pathogenic fungi on harvested seed. Journal of Plant Protection Research 46 (3): $295-311$.

Budzyński W., Ojczyk T. (red.). 1996. Rzepak, produkcja surowca olejarskiego. ART, Olsztyn, 186 ss.

Dunker S., Tiedemann A. 2004. Disease/yield loss analysis for Sclerotinia stem rot in winter oilseed rape. Integrated protection in oilseed crops. IOBC/WPRS Bulletin 27 (10): 59-65.

Grant C.A., Bailey L.D. 1993. Fertility management in Canola production. Canadian Journal of Plant Science 73: 651-670.

Gwiazdowski R., Wójtowicz M., Wójtowicz A. 2004. Wpływ warunków meteorologicznych na porażenie rzepaku ozimego przez grzyby z rodzaju Alternaria i Botrytis. [Influence of meteorological conditions on infestation of winter oilseed rape by fungi of genera Alternaria and Botrytis]. Progress in Plant Protection/Postępy w Ochronie Roślin 44 (2): 724-727.

Humpherson-Jones F.M. 1992. Epidemiology and control of dark leaf spot of brassicas. p. 267-288. In: „Alternaria Biology, Plant Diseases and Metabolites" (J. Chełkowski, A. Visconti, eds.). Topics in Secondary Metabolism. Vol. 3, Elsevier Science B.V., Amsterdam, $250 \mathrm{pp}$.

Jajor E., Wójtowicz M., Pieczul K. 2008. Wpływ warunków hydrotermicznych i terminu ochrony fungicydowej na występowanie grzybów z rodzaju Alternaria na rzepaku. [Influence of weather conditions and date of fungicidal control on occurrence of $\mathrm{Al}$ ternaria spp. on oilseed rape]. Progress in Plant Protection/Postępy w Ochronie Roślin 48 (3): 1048-1054.

Jajor E., Horoszkiewicz-Janka J., Wickiel G. 2013. Wpływ ochrony przy użyciu fungicydów na ograniczanie występowania grzybów na łuszczynach i nasionach rzepaku. [Influence of fungicide application on limitation of fungi on oilseed rape siliques and seeds]. Progress in Plant Protection/Postępy w Ochronie Roślin 53 (4): 768-773.

Kotecki A., Malarz M., Aniołowski K. 2001. Wpływ nawożenia azotem na skład chemiczny nasion pięciu odmian rzepaku jarego. Rośliny Oleiste - Oilseed Crops XXII (1): 81-89.

Kotecki A., Kozak M., Malarz W. 2004. Wpływ zróżnicowanego poziomu agrotechniki na rozwój i plonowanie odmian rzepaku ozimego. Rośliny Oleiste - Oilseed Crops XXV (1): 97-107.

Koźmiński C., Michalska B., Czarnecka M. 1993. Ekstremalne warunki pogodowe. s. 194-240. W: „Czynniki plonotwórcze - plonowanie roślin" (J. Dzieżyc, red.). PWN, Warszawa - Wrocław, 476 ss.

Kulig B., Oleksy A., Pyziak K., Styrc N., Staroń J. 2010. Wpływ warunków siedliskowych na plonowanie oraz zróżnicowanie wybranych wskaźników roślinnych populacyjnych odmian rzepaku ozimego. Rośliny Oleiste - Oilseed Crops XXXI (1): 99-114.

Kulig B., Oleksy A., Pyziak K., Styrc N., Staroń J. 2012. Wpływ warunków siedliskowych na plonowanie oraz wielkość wybranych wskaźników wegetacyjnych zrestorowanych odmian rzepaku ozimego. Fragmenta Agronomica 29 (1): 83-92.

Kutcher H.R., Warland J.S., Brandt S.A. 2010. Temperature and precipitation effects on canola yields in Saskatchewan. Agricultural and Forest Meteorology 150 (2): 161-165.

Mączyńska A., Krzyzińska B., Drzewiecki S. 2001. Wpływ różnych terminów stosowania fungicydów na zdrowotność łuszczyn rzepaku ozimego. [Influence of different terms of application of fungicides on health of winter rape pods]. Progress in Plant Protection/Postępy w Ochronie Roślin 41 (2): 638-642.

Mendham N.J. 1995. Physiological basis of seed yield and quality in oilseed rape. p. 485-490. In: Proceedings of the 9th International Rapeseed Congress "Rapeseed today and tomorrow". UK, Cambridge, 4-7 July 1995, 1447 pp.

Muśnicki Cz. 1989. Charakterystyka botaniczno-rolnicza rzepaku ozimego i jego plonowanie w zmiennych warunkach siedliskowoagrotechnicznych. Roczniki Akademii Rolniczej w Poznaniu, Rozprawy Naukowe 191: 4-154.

Muśnicki Cz., Toboła P., Muśnicka B. 1999. Wpływ niektórych czynników agrotechnicznych i siedliskowych na jakość plonu rzepaku ozimego. Rośliny Oleiste - Oilseed Crops XX (2): 459-469.

Murawa D., Warmiński K. 2005. Wpływ zróżnicowanej ochrony roślin na skład chemiczny nasion rzepaku jarego. Acta Scientiarum Polonorum, Agricultura 4 (1): 77-87.

Nowak W., Sowiński J., Pietr S.J., Kita W. 2005. Wpływ sposobów ochrony pszenicy ozimej na jakość ziarna konsumpcyjnego. Pamiętnik Puławski 139: 117-127.

Rimmer S.R., Shattuck V.I., Buchwaldt I. 2007. Compendium of Brassica Diseases. APS Press, St. Paul, MN, 117 pp.

Shrestha K.S., Munk L., Mathur B. 2005. Role of weather on Alternaria leaf blight disease and its effect on yield and yield components of mustard. Nepal Agriculture Research Journal 6: 62-72.

Szukała J., Mystek A., Kurasiak-Popowska D. 2006. Wpływ fungicydów na zdrowotność, plonowanie i wartość siewną łubinu białego i żółtego. [Influence of fungicides on plant health, yielding and seeding value of white and yellow lupine's]. Progress in Plant Protection/Postępy w Ochronie Roślin 46 (2): 636-640.

Wałkowski T. 2012. Znaczenie kwalifikowanego materiału siewnego w technologii produkcji rzepaku. Rośliny Oleiste - Oilseed Crops XXXIII (2): 235-244.

Wielebski F. 2009. Reakcja różnych typów hodowlanych odmian rzepaku ozimego na poziom stosowanej agrotechniki. Część II. Jakość zbieranego plonu. Rośliny Oleiste - Oilseed Crops XXX (1): 91-101. 